\title{
Confrontations in the New World: \\ Grete Weil's Happy, sagte der Onkel (1968) \\ Laureen Nussbaum
}

$\mathrm{n}$ her essay "Travel Writing and Gender," the British scholar Susan
Bassnett makes two points that are relevant in analyzing Grete Weil's travel tales, Happy, sagte der Onkel (Happy, Said My Uncle). ${ }^{1}$ Bassnett remarks that "increasingly in the twentieth century, male and female travelers have written self-reflexive texts that defy easy categorization as autobiography, memoir, or travel account." 2 This observation certainly hold true for Grete Weil's slim volume, and so does Bassnett's gender-specific assertion that there is a "strand of women's travel writing that has grown in importance in the twentieth century: the journey that leads to greater self-awareness and takes the reader simultaneously on that journey." ${ }^{3}$

The three stories told in Happy, sagte der Onkel are based on the author's first trip to the New World, but go beyond mere travel accounts. Starting from perspicacious observations about her novel surroundings, they progress to probing introspection. This trend becomes more compelling with each subsequent story, leading the narrator and the reader to greater self-awareness.

Margarete (Grete) Dispeker was born in 1906 in Egern, Upper Bavaria; her father was a highly respected lawyer in Munich. The family's many friends were mostly progressive intellectuals and artists. Grete's secular upbringing was rich in stimulation, including mountaineering and skiing, extensive reading, theatre visits and foreign travel. She studied German Language and Literature at several universities and started early 1932 on her doctoral dissertation. Later that year, she married Edgar Weil, a second cousin and fellow Germanist, whom she had known from childhood. They settled in Munich, where he had accepted a position as dramaturge at the Kammerspiele. Grete tried her hand and writing, without attempting to publish at the time. Within a year, Hitler had come to 
power and the board of directors of the avant-garde Kammerspiele was arrested. Soon everyone was released except for Edgar Weil, the only Jewish board member. When he was finally set free, Edgar and Grete decided to leave Germany; a most difficult decision for two Germanists who were deeply rooted in the German language and culture and who had no marketable skills with which to start a new life. Edgar apprenticed himself in his parents' pharmaceutical factory in Frankfurt and was soon able to open a small branch of the firm in the Netherlands. Grete learned professional photography in Munich, then followed him to Amsterdam in 1935.

The twelve years in Dutch exile were most traumatic for Grete Weil, and they became thematic in her later books. Until the outbreak of World War II and the subsequent German occupation of the Netherlands, the young couple made reasonable living but felt culturally isolated and increasingly worried about family members left behind in Germany. Grete's beloved father died at a timely moment, in 1937, before the deportation and extermination of Jews began. Her brother emigrated to England and, by subterfuge, Grete succeeded in bringing her mother to the Netherlands. That country was overrun in May 1940 by the German Army and soon the Nazis enacted repressive laws against Jews in the occupied Netherlands. The systematic rounding up of the Jewish population started in July 1942, but in June 1941, Edgar was quite arbitrarily apprehended in the street and - together with a few hundred refugee youths — sent to Mauthausen concentration camp, with its notorious quarry. There he was murdered within three months. The violent death of her husband left Weil with a life-long emotional wound. She contemplated suicide, but refrained in order to take care of her mother by accepting a job with the Jewish Council in Amsterdam, which temporarily protected both women from deportation. In September 1943, the last remnant of the Jewish population was to be sent to the death camps, Weil and her mother went into hiding and managed to survive the war.

Weil put her photographic skills to good use by providing the Dutch underground with pictures needed for falsified identity cards, and she kept her 
illegal work while in hiding. After a hiatus of 10 years, she also resumed writing. Her short story Ans Ende der Welt (To the End of the World) was completed in 1945, shortly after the end of the war. It is a differentiated fictional account of some of her harrowing observations and experiences as a clerk for the Jewish Council in Amsterdam's Joodsche Schouwburg, The Jewish Theatre, where apprehended Jews were processed before being deported to the death camps.

From then on, Weil made it her task as a writer to witness against forgetting. Since she saw herself as a German writer and the German culture as her culture, she re-migrated to West Germany as early as 1947. Many years later, she remembers in an interview: "Germany was as broken as I myself, and that was just what I needed. At first one also had the feeling that one could really help rebuild."4 Moreover, Weil had friends among progressive West German intellectuals and artists, in particular the stage director Walter Jockisch, whom she married in 1960. Unfortunately, she could not find a publisher for her short story in the Federal Republic. In 1949, it appeared in the German Democratic Republic, where it was much acclaimed, as was a Dutch translation one year later in the Netherlands. The book was totally ignored in the Federal Republic. Disappointed, Weil limited her literary activities through the 1950s to two libretti, ${ }^{5}$ several theatre reviews ${ }^{6}$ and the translation of novels from English for Limes in Wiesbaden. In 1962, this West German publishing house decided to bring out a new edition of Ans Ende der Welt, which greatly encouraged the author to continue working on her next novel.

This new novel, Tramhalte Beethovenstraat, set in occupied Amsterdam, was Weil's attempt to bridge the gap between her compulsion to bear witness and the complacency she observed in West Germany in the early 1960s, the era of Adenauer's Wirtschaftswunder. Her main character, a young, politically naïve German writer, stationed in war-time Amsterdam as a reporter for a Munich newspaper, is drawn into the fate of his Jewish neighbors as he witnesses the nightly roundups of bewildered Jews at the Beethovenstraat streetcar stop just below his window. Limes published the novel in 1963 and it was well reviewed. 
Yet, far from causing the breakthrough Weil had hoped for, the novel found little readership in the Federal Republic. Only in the 1970s would a new generation of Germans try to come to grips with their country's recent past. The Dutch translation, however, made a name for the author in the country of her exile.

Grete Weil was still largely unrecognized in West Germany when, in the winter of 1964-65, she visited family and friend in the New World. In her three travel stories, published in 1968 by Limes, the author writes in succinct style and employs the auctorial voice which gives her accounts the persuasive immediacy that is henceforth typical for her writing. In the title story, Happy, sagte der Onkel, set in greater Los Angeles, the narrator walks the length of Wilshire Boulevard to visit her "Californian" uncle and aunt, refugees from Munich. Since she is the only one of foot, she finds the long street boring and ugly despite individual well-kept front gardens with shrubs flowering in mid-winter. It is impossible for her to tell the real from the artificial: a blue bird, which looked to her like a well-made counterfeit, unexpectedly flies away. In front of a flower store she notes that she is:

overwhelmed by the splendor of forsythias, vetch, tulips, narcissus, roses, lilies of the valley, dahlias and asters. Yet, all of it was make-believe, dust covered artificiality; way back, in a show-case, chrysanthemums and orchids prolonged their refrigerated life. Artificial flowers are hygienic, they do not carry any vermin into the house, save work and expenses and by their permanence feign eternal youth. Youthfulness, the highest of all virtues, the illusion of vitality till death and beyond, corpses with pink make-up on silk pillows. $^{7}$

In the mid-1960s, this contrast between the "cheerfulness" of sunny California and the grayness of war-torn Western Europe was still stark and bewildering. To the narrator's relief she notices a familiar sight on Hollywood Boulevard: a group of young people "hanging out arm in arm, long-haired boys and girls in blue jeans, just like in Saint Germain and Schwabing." 8 Sharing their disgust with her 
own contemporaries, the narrator pins her hope for the future on these young people and their generation worldwide (Weil, 12).

However, the narrator has to cope with the here and now of her seemingly endless walk. Heavy smog — not mentioned in the travel brochures she had studied long before her trip - catches up with her. It is a new phenomenon, she was told, because of the enormous increase in cars and factories, "the six million fog of prosperity" (Weil, 12). What would she answer to the ever-repeated question of how she likes America? "No opinion, Mr. Gallup, however painful this confession" (Weil, 13). She had become a well-educated, well-traveled polyglot with an interest in art and politics, and she had thought she knew the US quite well before her arrival. However, what she experiences is very different:

Confusion already upon leaving the airplane. Perfect technical devices, but where this perfection ends, blatant primitively, the artificial bird that is alive, the life-like flowers that are artificial, skyscrapers and shacks, erudition and naiveté, highly intense spirituality and self-satisfied humdrum routine, iron-barred windows and open doors. ${ }^{9}$

Contrasts and contradictions everywhere. Yet, as the sun sets, the narrator witnesses a magic display of colors that transforms the edge of the drab desert. It is so glorious that, to her amazement, she starts "thinking in superlatives" typical for the US. Then suddenly, night falls (Weil 17).

The many contrasts and contradictions experienced on her long walk home of her uncle and aunt are just a prelude to what is awaiting the narrator there. She is struck by the frantic attempt of these elderly relatives to project themselves as super-Americans. Sitting at the edge of the desert among their stately European furniture, they loudly praise the land of freedom and democracy, throwing in bits of English. Yet, they are mortally afraid of falling sick, "Illness is for the rich only in this country."10 Despite their irascible rejection of everything German, and their unreflected, total repudiation of their previous lives, sentimental memories of their homeland - especially of Munich — keep welling up. They 
are happy but not glücklich, have learned nothing from their experiences, and do not want to hear from their visiting niece how their closest kin were rounded up and killed. The story ends with an absurd quarrel between uncle and aunt, as the narrator slips away from this painful confrontation. It is up to the reader to realize that the Jewish refugees depicted here have no more come to grips with the Nazi era than the mass of the German population. While the narrator in this story remains a critical outsider, who observes without growing wiser from her experience, the author leads her readers to a new awareness not only of the many contradiction in greater Los Angeles, but more trenchantly of the incongruities inherent in the life of refuges, carried to grotesque extremes by the elderly couple of her tale.

The narrator's involvement becomes considerably more intense in the story "Gloria Halleluja," set in New York City, her last stop in the US. Quite satisfied with her travel sequence from the West to the East, she muses: "If a person wants to see America this [New York City] should be the last place to go, for if this city were to be the first stop, one would not leave. One would forget about all of the mountains and all of the oceans and all of the lakes" in order to descend into the subway and explore New York's diverse neighborhoods, both the ethnic ones and the ones inhabited by the super-rich facing Central Park with its "trees, meadows, ponds, rocks, with children riding ponies and with poetryinspiring squirrels" (Weil 37). In other places, surfacing from the subway, "one would be unable to see the sky. Walls made out of stone, walls made out of cement and walls made out of dark glass that mirror other walls, but what happened behind them, they do not disclose; and all of them taken together form a big mountain range, challenging like the 'Rosengarten' [mountain in Southern Tyrol] and not a bit less romantic. Temptation and dream" (Weil 38).

She reflects on the diminutive church, cramped in between the skyscrapers near the stock exchange. "Do the dealers come to pray before or after going to the stock exchange? Do they whisper entreaties or thanks? What takes them to their 
God?" (Weil 38). One would ride the relaxed and inexpensive ferry to Staten Island "past the hypertrophic statue of liberty, facing the skyline, known for having been the promise of a new and better life for countless people" (Weil 38). One would cross the spectacular bridges that connect Manhattan with Brooklyn, with Queens and with Hoboken and one would see the people of color everywhere "but one would never get to Harlem."11 Yet that is where the narrator, who feels drawn to the under-privileged, insists on going, however strongly her New York friends try to dissuade her.

No longer just an observer, the narrator makes herself vulnerable on the bus to Harlem as soon as she finds herself the only white person left. Fellow passengers begin to stare at her. In her uneasiness, she does exactly what she has always deeply despised in others:

"I took notice of the fact that the driver was a white man and felt relief. Declared my solidarity with his fat neck. Was convinced that these coarse hands that clasped the wheel would protect me. Even before I had really set foot in Harlem, I had got myself caught in the vicious circle of fear and prejudice." ${ }^{12}$

A young boy taunts her. For a moment she feels disoriented and very insecure, then she gets off at the corner of Lenox Avenue and 125th, Harlem's main shopping street. This street with its provincial, lower middle class stores shocks the narrator more than the hopelessly neglected black streets of New Orleans close to the French quarter, "the vaunted tourists attraction of the South" (Weil 46). Black streets in New Orleans "shamelessly demonstrate the victory of one race over another," whereas Harlem's Main Street appears harmlessly petty bourgeois at first sight "and yet it is avoided by white people, as if they might catch leprosy or the plague there." ${ }^{13}$ Noticing the large contingent of white, tall, burly, brutal-looking policemen, three of them at each street corner, she is inclined to consider them as enemies, both on the strength of her experiences with authorities of law and order during the Nazi years and because, in their eyes, she evidently has no business being in the black neighborhood (Weil 47). 
The narrator contrasts her attempt to confront life in Harlem with the "play-it-safe" approach of visitors in a passing routing coach, who dutifully take pictures of whatever their travel guide points out from behind the bus windows (Weil 47). She peers into the stores and notices that they are run by white people, "Jews all of them, German, Polish, Russian, fled from Hitler or already earlier from the pogroms of the East, but at one point they or their fathers looked from aboard a ship to the country of milk and honey, in which there are people even more disfranchised than they." ${ }^{14}$ They go home at night

"to the Lower East and the Bronx, despising the negroes, hated by the negroes, and here I go, one of them, separated from their fate by just two or three generations...and compare the Jews of Harlem with the Negroes of Harlem, the Negroes of Harlem with those in the South, the Jews of Europe with the Jews of America, the Negros of Africa with the Jews of Israel, the Jews of the concentration camps with the Negro slaves, Harlem with Warsaw, but no equation can be solved, every time $\mathrm{x}$ is a different entity, a different enemy, threatening with annihilation." 15

This self-reflective passage illustrates how the author goes well beyond giving a travel account in her search of deeper awareness.

Moving from the outside to the inside, Weil has her narrator visit the home of the young black woman who had guided her and other tourists at the United Nations building the day before. Welcomed by the guide's large, congenial family, who live in a one-room apartment, the narrator tries to blend in, yet remains an outsider. Her identification with the plight of American blacks does not automatically bring her closer to them. After some Gospel singing and a simple meal, the visitor is asked whether all Germans had been Nazis. "Certainly not I," she answers. "I am a Jew." ${ }^{16}$ Upon this revelation, she is called a murderer of the Lord and summarily ordered out of the house. Subsequently, as a sequel to her previous musings about Negroes and Jews, the narrator find herself at a local pawnbroker's, who - like herself — is of German Jewish origin. The 
pawnshop is a depressing place, where poor black people are mercilessly fleeced. Another confrontation follows. The pawnbroker, the onerous camp number tattooed on her arm, had been victim of the Nazi's medical experiments. Here, too, the narrator's empathy does not bridge the gap. Upon learning that the foreign visitor to her shop had re-migrated to Germany, the pawnbroker vociferously chases her out into the cold (Weil 58-61). A third confrontation follows, after the narrator and her black friend, the UN guide, enter a bar to warm up. They drink too much and so do the surrounding black men. When the latter start singing aggressively, the narrator's woman friend joins in. She is unable to protect the terrified narrator from being physically thrown out. Shaken by this string of confrontations to the point of hallucinating, the narrator flees Harlem on a southbound bus (Weil 62-67). Face to face encounters have not brought any solutions, but they have heightened the narrator's and the reader's awareness of the enormity of the problems facing American society. Clearly, sincere empathy with the victims of discrimination and goodwill towards them are necessary but are still insufficient to bring about mutual respect and cooperation for a better future.

In Weil's third story, "B sagen" (literally "to say B;" the expression means: taking the consequences) the narrator faces her most challenging confrontation, which leads to a breathtaking catharsis. After flying to Mérido on the Yucatan Peninsula to bask in a warmer climate, she takes a local bus to Chichén-Itza, the site of Toltec ruins. She notices poor villages and lush jungle along the road and, unlike a US fellow-passenger, she is not bothered by the abundance of vultures, which are circling the sky, ready to swoop down on run-over dogs and other carrion. She knows how to face death! At the archeological site, near the gloomy Temple of the Warrior, she muses about the cruelty of people, at the time of the Toltecs as well as now. Those in power always have a good rationale, she observes (Weil 75).

As she gazes at a platform evenly covered with rows upon rows of skulls, she is suddenly surrounded by a US-American tour group. The suave tour guide says: "Here is where they kept the skulls of their sacrifices...The Black Wall of 
the Toltecs."17 This immediate association with the black wall of recent executions in Auschwitz, combined with the supercilious demeanor of the group's guide, unnerves the narrator. When has she witnessed similar deportment before? She is struck by the resemblance between the disdainful guide and a haughty high-ranking SS officer at the Jewish Theatre in Amsterdam. Obsessed with the flashback to her wartime past, the narrator challenges the purported former Nazi officer in a merciless inner dialogue and calls him to account. How can he play the gentlemen-guide after having participated in the Nazi mass murders? But then, how can she herself travel all over the world, hungry for new impressions? Do he and she not share survival strategies just as they share a pre-Nazi German past in which neither of them was politically active enough to help stem the tide of National Socialism? Are they not both compromised by their affirmation of life, however jaded, after Auschwitz? - To have stayed alive is to have said, "A," and hence both of them have had to take the consequence and say "B," - which is to go on living with unbearable memories (Weil 98-108). Unsparing sincerity brings the narrator to painful catharsis, even while the putative ex-SS officer gallantly lights his cigarette in the lobby of the Chichén-Itzá hotel.

In all three travel tales of Happy, sagte der Onkel, Grete Weil has her narrator move from the peripheral - the long walk along Wilshire Boulevard, the exploration of the New York cityscape, and the bus ride to the Toltec ruins - to intense inter- and intra-personal confrontations, which grow more quintessential from one story to the next. These tales are both autobiographical travel accounts and self-reflexive texts in Susan Bassnett's sense. ${ }^{18}$ Using her travel adventurers in North America as a foil, the author leads her readers inescapably to more differentiated thinking and hence to greater awareness. Moreover, in the process of creating literature out of the challenges she met in the new world, Weil found her own narrative voice. Henceforth, she uses an auctorial narrator with great effect in practically all of her writing. Falling back time and again upon her crucial experiences during the Hitler years, she allows herself to remain 
vulnerable. Her books keep blending acute observations with her extraordinary courage in confronting herself unsparingly.

After her pivotal travel stories, Weil's next novel, Meine Schwester Antigone (My Sister Antigone), published in $1980,{ }^{19}$ finally brought the breakthrough she deserved. By then she was 74 years old and again widowed. She lived alternately in Munich and near Locarno, above the Lago Maggiore, and continued to witness against forgetting. From her travels to Asia she brought home beautiful portraits but no travel tales. By the time she died in 1999, she had written two more novels, another collection of soul-searching stories and an autobiography. ${ }^{20}$ Moreover, she had earned several prestigious literature prizes ${ }^{21}$ of which the Geschwister-Scholl-Preis meant most to her, since it honors "not just literature bur foremost basic attitude"22 and because it ties in directly with her wartime experiences and with her Antigone book, which is an exploration of courageous resistance (ibid.). Although her first confrontation with the New World was not a decisive experience in Grete Weil's long life, it turned out to be an invaluable catalyst for Weil, the author. The three travel tales make a fascinating and challenging read, but far more importantly, writing Happy, sagte der Onkel helped Weil find her very special, succinct style and unique voice while deepening her self-awareness. 


\section{Works Cited}

Bassnett, Susan

2002 „Travel Writing and Gender.“.In Peter Hulme and Tim Youngs (eds.), The Cambridge Companion To Travel Writing, 225-241. Cambridge: Cambridge University Press.

Exner, Lisbeth

$1998 \quad$ Land meiner Mörder, Land meiner Sprache. Die Schriftstellerin Grete Weil. München: A-1Verlag.

Meyer, Uwe

1996 Neinsagen, die einzige unzerstörbare Freiheit. Das Werk der Schriftstellerin Grete Weil. Frankfurt/Berlin: Peter Lang.

Nussbaum, Laureen and Meyer, Uwe,

1993

„Grete Weil, unbequem, zum Denken zwingend.“ In Claus-Dieter Krohn (ed.) Frauen und Exil. Exilforschung ein internationales Jahrbuch, Vol. 11; 156-170. München: Text und Kritik.

Weil, Grete

1949

1963

1968

1980

1981

1983

1988 a

1988 b

1992

1998
Ans Ende der Welt. Berlin: Volk und Welt.

Tramhalte Beethovenstraat. Wiesbaden: Limes. Happy, sagte der Onkel. Wiesbaden: Limes. Meine Schwester Antigone . Zürich: Benzinger. „Nicht dazu erzogen Widerstand zu leisten.“ In Edith Laudowicz and Dorlies Pollmann (eds.), Weil ich das Leben liebe, 171-180. Köln (Cologne): Pahl-Rugenstein, Generationen. Zürich: Benzinger.

Der Brautpreis. Zürich: Nagel \& Kimche. „Nicht das ganze deutsche Volk." "Grete Weil bei der Verleihung des Geschwister Scholl Preises.“ Süddeutsche Zeitung, Nr. 269, Nov. 22, 1988; 10.

Spätfolgen. Zürich: Nagel \& Kimche Leb ich denn, wenn andere leben. Zürich: Nagel \& Kimche

${ }^{1}$ Weil 1968. For this essay a later edition, Fischer Taschenbuch \#5254 (Frankfut, 1982) was used. Unless referring to secondary materials just quoted from, the numbers in parenthesis in text and notes point to pages in the Taschenbuch edition.

${ }^{2}$ Bassnett (225).

3 ibid. (237).

${ }^{4}$ Grete Weil, 1981 (179). 
The translations in this essay are all its author's. The original reads: "Deutschland war ebenso kaputt wie ich selbst, und das war genau das Richtige für mich. Zunächst hat man ja auch das Gefühl gehabt, daß man wirklich beim Wiederaufbau helfen kann"

${ }^{5}$ The more successful of the two was Hans Werner Henze's opera Boulevard Solitude, premiered in Hannover Feb. 17, 1952.

${ }^{6}$ 1956-58 for Das neue Forum, published in Darmstadt.

7 "hingerissen von der Pacht der Forsythien, Wicken, Tulpen, Narzissen, Rosen, der Maiglöckchen, Dahlien und Astern. Doch es war Schwindel, alles Schwindel, verstaubte Künstlichkeit, ganz hinten in einer Vitrine fristeten Chysanthemen und Orchideen ihr durch Eiskühlung verlängertes Leben. Kunstblumen sind hygienisch, bringen kein Ungeziefer ins Haus, ersparen Arbeit und Ausgaben und täuschen durch ihre Beständigkeit ewige Jugend vor. Jungsein, die Höchste aller Tugenden, der Schein der Vitalität bis zum Tod und über ihn hinaus rosig geschminkt Leichen auf seidenen Kissen," (Weil, 11).

8 "Arm in Arm herumschlendernde langhaarige Jungen und Mädchen in Bluejeans, wie in Saint Germain und Schwabing," (Weil, 11).

9 “[Es war] der Sechsmillionennebel der Prosperität, [. . . ]. Keine Meinung, Mr. Gallup, so peinlich mir dieses Bekenntnis auch ist. [...]. Verwirrung schon beim Verlassen des Flugzeugs. Die perfekte Technik, aber wo sie aufhört perfekt zu sein, krasse Primitivität, der künstliche Vogel, der lebt, und die lebendigen Blumen, die künstlich sind, Wolkenkratzer und Bruchbuden, Bildung und Naivität, hochgespannte Geistigkeit und ein selbstgenügsamer Schlendrian, vergitterte Fenster und offene Türen" (Weil, 12-13).

10 "Kranksein können sich hier nur die Reichen leisten" (Weil, 33).

11 "will man Amerika sehen, sollte man zuletzt hierherkommen, denn wäre diese Stadt die erste, ginge man nicht mehr fort. Man ließe alle Berge und alle Meere und alle Seen, [. . .]," to explore New York's neighborhoods including the one facing Central Park featuring "Bäume, Wiesen, Teiche, Felsen, auf Ponys reitende Kinder und poetogene Eichhörnchen” (Weil, 37). Emerging from the subway in another neighborhood it is possible "daß man .. . den Himmel nicht sähe. Wände aus Stein, Wände aus Beton und Wände aus dunklem Glas, die andere Wände spiegeln, aber das, was hinter ihnen geschieht, nicht preisgeben, und alle zusammen sind ein großes Gebirge, kühn wie der Rosengarten und um nichts weniger romantisch. Verlockung und Traum" (Weil, 38). "Gehen die Makler vor der Börse zum Gebet oder danach, flüstern sie Bitten oder Dank, was tun sie bei ihrem Gott?" (ibid.). The ferry ride to Staten Island goes "an der hypertropischen Freiheitsstatue vorbei, den Blick of die Skyline gerichtet, von der man weiß,daß sie unzähligen Menschen Verheißung eines neuen, besseren Lebens war. [. . .] Aber nach Harlem käme man nie" (ibid.).

12 “ich stellte fest, daß der Fahrer ein Weißer war und fühlte Erleichterung. Erklärte mich mit seinem feisten Nacken solidarisch. War überzeugt, daß diese groben, das Steuer umklammernden Hände mich schützen würden. Noch bevor ich Harlem richtig betreten hatte, war ich in den Teufelskreis von Furcht und Vorurteil geraten" (Weil, 43).

${ }^{13}$ Near the French Quarter, "der aufgeplusterten Touristenattraktion des Südens, ... Schamlos zur Schau getragener Sieg einer Rasse über die andere.” Harlem's 125th St. looks harmless by comparison "und die doch von den Weißen gemieden wird, als könnte man sich da Aussatz und Pest holen" (Weil, 46).

14 "Juden sind sie alle, deutsche, polnische, russische vor Hitler geflohen oder schon früher vor den Pogromen des Ostens, aber einmal haben sie oder ihre Väter vom Bord eines Schiffes aus das Land erblickt, in dem Milch und Honig fließt, in dem es noch Ausgestoßenere gibt als sie" (Weil, 50).

15 "nach Lower East und der Bronx, die Neger verachtend, von den Negern gehaßt, und da gehe ich, eine ihresgleichen, erst zwei oder drei Generationen von ihrem Schicksal getrennt [. . .] und vergleiche, die Juden Harlems mit den Negern Harlems, die Neger Harlems mit denen des 
Südens, die Juden Europas mit den Juden Amerikas, die Neger Afrikas mit den Juden Israels, die Juden der Vernichtungslager mit den Negersklaven, Harlem mit Warschau, aber keine Gleichung geht auf, jedesmal ist x eine andere Größe, ein anderer Feind, der mit Vernichtung droht” (Weil, $51)$.

16 "Ich bestimmt nicht. Ich bin Jüdin" (Weil, 56).

17 "Hier wurden die Schädel der Geopferden aufbewahrt [...]: Die Schwarze Wand der Tolteken" (Weil, 76)

${ }^{18}$ see note 2

${ }^{19}$ by Benziger in Zürich.

${ }^{20}$ The novels: Generationen (Weil 1983) and Der Brautpreis (Weil 1988a), the stories Spätfolgen (Weil 1992), the autobiography, Leb ich denn, wenn andere leben (Weil 1998).

${ }^{21}$ see for more information, Uwe Meyer 1996 and Lisbeth Exner, 1998. For a more compact, slightly dated overview see Laureen Nussbaum, Uwe Meyer1993.

22 "Gilt er ja nicht nur der Literatur [. . .] sondern vor allem der Gesinnung." Quoted from Weil 1988b. 